FACTA UNIVERSITATIS

Series: Economics and Organization Vol. 15, N $\mathrm{N}^{\mathrm{o}}$ 2, 2018, pp. $111-123$

https://doi.org/10.22190/FUEO1802111R

Original Scientific Paper

\title{
THE ROLE OF TECHNOLOGICAL READINESS IN THE GLOBAL COMPETITIVENESS OF SERBIAN ECONOMY
}

UDC 334.34:62(497.11+497)

\author{
Vladimir Radivojević ${ }^{1}$, Bojan Krstić ${ }^{2}$, Tanja Stanišić ${ }^{3}$ \\ ${ }^{1}$ Regional Centre Niš, Ministry of Defense, Serbia \\ ${ }^{2}$ Faculty of Economics, University of Niš, Serbia \\ ${ }^{3}$ Faculty of Hotel Management and Tourism in Vrnjačka Banja, University of Kragujevac, \\ Serbia
}

\begin{abstract}
Technological readiness has been an important determinant of the economic and social development in recent decades. Therefore, technological readiness has a substantial impact on the global competitiveness of national economies in the contemporary business environment. The purpose of this paper is to evaluate the level of Serbian economy competitiveness in terms of technological readiness and to identify the critical factors for its further development. The analysis is based on the data published by World Economic Forum in annual The Global Competitiveness Reports in the period from 2013 to 2017. The research is conducted through comparative analysis and benchmarking method. The results show significant deviations and negative trend of technological readiness of Serbia in comparison not only with European countries but alsowith Balkan countries. The conclusions of this research may serve as the directions for technological readiness policy makers in Serbia and other Balkan countries.
\end{abstract}

Key words: technological readiness, competitiveness, Serbia, Balkan countries, European countries.

JEL Classification: Q55, O33, 057

\section{INTRODUCTION}

Technological readiness is one of key growth elements in every national economy. It is almost impossible to imagine any aspect of human activity without the use of technology tools.

Received February 07, 2018 / Revised April 12, 2018 / Accepted April 17, 2018

Corresponding author: Vladimir Radivojević

Ministry of Defence, Regional Centre Niš, Serbia

E-mail: vladimir.radivojevic@ymail.com 
Furthermore, technology has a substantial role in creating the way of living, working, communicating, and playing in the modern society. Considering such important role in social life and business operations, the results achieved in technological readiness largely define the quality of citizens' life and the attractiveness of the economy in a particular country. Consequently, the level of competitiveness in terms of technological readiness to a great extent determines the general competitiveness of the national economy in a globalised world. These are the key reasons why technological readiness requires special treatment in designing the strategic development of a country and why it should be monitored and improved in each national economy that advocates an open development model.

The level of technological readiness development varies from region to region, i.e. from country to country. Europe has been the leading region in the field of technological readiness in the world for many years. According to World Economic Forum (2017-2018), there are seven European countries in the world's top ten most developed economies in terms of technological readiness. However, although Europe as a region achieves impressive results in this area, the level of technological readiness development diverges among European countries. Furthermore, there are large differences of the development level even within the European Union (EU). Thus, it is expected that greater differences exist between EU countries and other European countries that are not EU members, such as some Balkan countries.

The intention of this paper is to evaluate the level of competitiveness of Serbia and other Balkan countries in the field of technological readiness, through benchmarking the results achieved by Balkan countries with the results achieved by top European countries. The purpose is to identify the factors of technological readiness that are critical for competitiveness of Serbia and other Balkan countries, i.e. factors that require a priority in the development policy of Balkan countries with the aim of bridging the gap with the top European destinations in the future. The study is useful to policy makers of Balkan countries in the process of defining development goals and implementing strategic plans in the field of technological readiness.

This paper contains four separate segments. The first segment of the paper provides a theoretical background and literature review. Research methodology and data basis are defined in the second segment of the paper. The research results are presented and discussed in the third segment. The last segment summarizes the conclusions and recommendations for improving the technological readiness in Serbia and other Balkan countries.

\section{THEORETICAL BACKGROUND AND LITERATURE REVIEW}

Countries and companies in the globalized market are permanently faced with the need to change and develop its structures, processes, and technologies. Continuous improvement of these segments provides survival in the market and gaining competitive advantage. At almost each segment of the country and company strategic planning there are technologyrelated decisions as well as the use of technologies with different characteristics in nature (Oztemel \& Polat, 2006; Petković \& Lukić, 2014). These decisions have a huge impact on all their business operations.

There are numerous studies in the economic literature that examine some of the aspects of technological readiness. One of these aspects refers to e-readiness, which is defined as "the ability of a country, enterprise or organizational unit to be prepared, willing to adopt, use and benefit from e-innovations such as e-business, e-government, e-procurement, elearning, etc." (Lou, 2010, quoted in: Aboelmaged, 2014, p. 639). Most of the studies 
examine e-readiness on the country-level (Bui, Sankaran \& Sebastian, 2003; Mutula \& van Brakel, 2006; Hanafizadeh et al., 2009; Seyed \& Sattary, 2009), but there are also studies which test the impact of e-readiness on the firm-level (Naseebullah et al., 2011; Heeks et al. 2011; Muafi et al., 2012; Aboelmaged, 2014; Gilabert et al., 2014). The authors of these studies argue that e-readiness is one of the crucial factors for improving performances and competitiveness of companies, industries, and even the whole economy.

An important prerequisite for successful development of technological readiness (on the country-level or firm-level) is the existence of efficient information and communication technologies (ICT). Therefore, there is a lot of empirical evidences in the literature that examines the influence of ICT on business operations and firms' performances, but also on productivity and competitiveness of national economies. Some of them analyse the impact of the ICT on development and competitiveness of the hospitality sector (Siguaw, Enz \& Namasivayam, 2000; Ham, Kim \& Jeong, 2005; Mosleh \& Shannak, 2009), tourism industry (Buhalis \& Zoge, 2007), and hotel sector (Avcikurt et al., 2011; Mihali et al., 2015). Research findings of these studies point out to the importance of ICT in simpler, lowcost, and better service provision in these sectors. Other studies (Ray et al., 2004; Gursoy \& Swanger, 2007; Spyros et al., 2011) are related to different factors of ICT which represent important resources in the process of gaining sustainable competitive advantage. For example, Piccoli (2004), McAfee \& Brynjolfsson (2008), and Lukić \& Mirković (2014) consider that investment in ICT is a facility to enhance productivity and reduce costs.

Opposite to the above-mentioned studies, there are researches as Mihalič, Praničević \& Arnerić (2015) which are based on the so-called ICT paradox theory. The authors of this theory argue that there is no significant impact of ICT investments on firms' value, firms' performance, and its competitive advantage (Willcocks \& Lester, 1999; Carr, 2004; Aral et al., 2006; Lee \& Connolly, 2010). However, dominant part of the technological readiness researches confirm its great significance in economic and social development of national economies, but also in successful business operations of firms in a globalized market.

\section{RESEARCH METHODOLOGY AND DATA BASIS}

The aim of this research is to analyse the level of Serbian economy competitiveness in terms of technological readiness, but also to identify the critical factors for improving the competitive position of Serbia in this field in the future. The identification and analysis of factors that determine technological readiness competitiveness of the national economies are based on the methodology of the World Economic Forum. Secondary data published in the Global Competitiveness Report in the period from 2013-2014 to 2017-2018 represent the data basis for the research.

The World Economic Forum (WEF) in its Global Competitiveness Report (2017-2018, p. 11) define competitiveness as ,the set of institutions, policies, and factors that determine the level of productivity of an economy, which in turn sets the level of prosperity that the economy can achieve“. Based on this definition, WEF ranks countries according to their results (scores in the interval from 1 to 7) that are summarized in the Global Competitiveness Index (GCI). The GCI is a composite index that combines 114 indicators which are grouped in 12 pillars.

The Technological readiness pillar is the ninth pillar of GCI, by which WEF captures key technological aspects of national competitiveness in one measure that allows comparisons across countries and over time. It consists of the following 7 indicators: 
(1) Availability of latest technologies;

(2) Firm-level technology absorption;

(3) Foreign direct investment (FDI) and technology transfer;

(4) Internet users (\% pop.);

(5) Fixed-broadband Internet subscriptions (/100 pop.);

(6) Internet bandwidth (kb/s/user) and

(7) Mobile-broadband subscriptions (/100 pop.).

The analysis of technological readiness competitiveness of Serbia in this research does not pretend to specify and formulate a unified recommendation for technological readiness development policy. The purpose of this paper is to identify the critical factors of technological readiness competitiveness of Serbia and other Balkan countries. Benchmarking of the results achieved by Balkan and top ten European countries is used to determine the critical indicators as segments of the technological readiness development policy of Serbia and other Balkan countries in the future period.

The following ten Balkan countries are included in the analysis: Albania, Bosnia and Herzegovina, Bulgaria, Croatia, Greece, Macedonia, Montenegro, Romania, Serbia, and Slovenia. Since the study involves ten Balkan countries, the authors define the following group of top ten European countries (according to global rank in terms of technological readiness) as a benchmarking group: Denmark, Finland, Germany, Iceland, Luxembourg, Netherlands, Norway, Sweden, Switzerland, and the United Kingdom.

\section{RESEARCH RESULTS AND DISCUSSION}

\subsection{Analysis of score and rank of Serbia in the Technological readiness pillar}

The analysis of technological readiness competitiveness of Serbia is based on data about score and rank of this pillar in GCI. Table 1 indicates the score and rank of Serbia in the Technological readiness pillar in the period from 2013-2014 to 2017-2018.

Table 1 The score and rank of Serbia in Technological readiness pillar of GCI (from 2013-2014 to 2017-2018)

\begin{tabular}{lccccc}
\hline Year & $\begin{array}{c}\text { Number of } \\
\text { surveyed } \\
\text { countries }\end{array}$ & Technological readiness pillar & \multicolumn{2}{c}{$\begin{array}{c}\text { Changes in Technological } \\
\text { readiness pillar }\end{array}$} \\
\hline $2013-2014$ & 148 & 3.9 & Rank & Score & Rank \\
$2014-2015$ & 144 & 4.4 & 60 & - & - \\
$2015-2016$ & 140 & 4.5 & 51 & +0.5 & +11 \\
$2016-2017$ & 138 & 4.1 & 70 & -0.1 & -2 \\
$2017-2018$ & 137 & 4.2 & 72 & +0.1 & -19 \\
\hline Total* & - & - & - & +0.3 & -12 \\
\hline \multicolumn{7}{c}{ * Note: The results obtained by comparison of score and rank in 2013-2014 and in 2017-2018 } \\
\multicolumn{5}{c}{ Source: World Economic Forum, The Global Competitiveness Report, } \\
\end{tabular}

Table 1 shows that Serbia is located in the first half of the global list in terms of technological readiness in the period from 2013-2014 to 2015-2016, while in the period from 2016-2017 to 2017-2018 it belongs to the group of countries located in the second 
half of the global list. It is also important to note that Serbia has made moderate oscillations of results in the Technological readiness pillar in the mentioned period (from 2013-2014 to 2017-2018). The score ranged from 3.9 to 4.5, while the rank ranged from 49 to 72 , which is obvious considering that the number of surveyed countries in that period varied from 137 to 148 . It is also obvious that Serbia improved its score by 0.3 , and at the same time lowered its ranking by 12 positions.

Data presented in Table 2 indicate the score and rank of Serbia in GCI in the period from 2013-2014 to 2017-2018. Comparison of score and rank of Technological readiness pillar (Table 1) and score and rank of GCI (Table 2) provides insight into its interdependence, i.e. provides assessment of the impact of Technological readiness pillar onto the global competitiveness of Serbia.

Table 2 The score and rank of Serbia in GCI (from 2013-2014 to 2017-2018)

\begin{tabular}{lccccc}
\hline \multirow{2}{*}{ Year } & \begin{tabular}{c} 
Number of \\
surveyed \\
\cline { 3 - 6 }
\end{tabular} & \multicolumn{3}{c}{ GCI } & \multicolumn{2}{c}{ Changes in GCI } \\
\cline { 3 - 6 } & countries & Score & Rank & Score & Rank \\
\hline $2013-2014$ & 148 & 3.8 & 101 & - & - \\
$2014-2015$ & 144 & 3.9 & 94 & +0.1 & +7 \\
$2015-2016$ & 140 & 3.9 & 94 & - & - \\
$2017-2017$ & 138 & 4.0 & 90 & +0.1 & +4 \\
\hline Total* & 137 & 4.1 & 78 & +0.1 & +12 \\
$*$ Note: The results obtained by comparison of score and rank in 2013-2014 and in 2017-2018 \\
Source: World Economic Forum, The Global Competitiveness Report, \\
2013-2014, 2014-2015, 2015-2016, 2016-2017, 2017-2018
\end{tabular}

Analysis and comparison of data from Table 1 and Table 2 show that Technological readiness pillar has a strong impact on the global competitiveness of Serbia in the period from 2013-2014 to 2015-2016. In other words, changes in score and rank of Technological readiness pillar (Table 1) and changes in score and rank of GCI (Table 2) in the mentioned period are almost the same. However, this conclusion cannot be drawn from the same analysis for the period from 2016-2017 to 2017-2018. It is graphically illustrated in Figure 1.

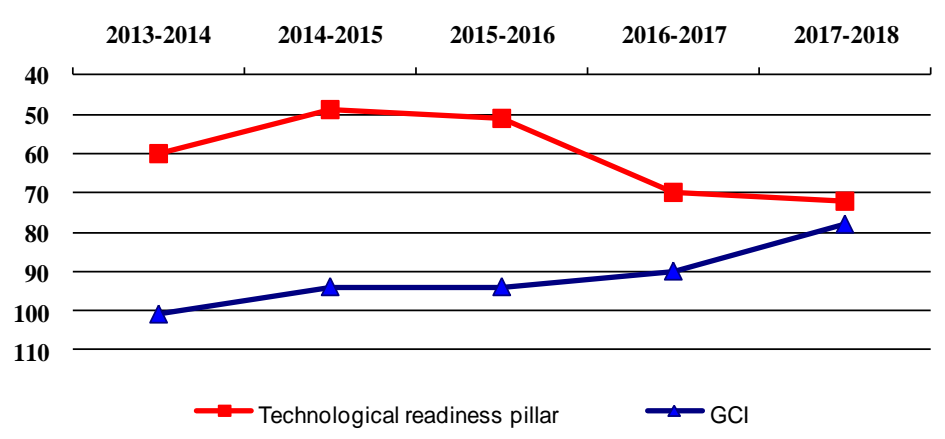

Fig. 1 Rank of Serbia in the Technological readiness pillar and GCI (from 2013-2014 to 2017-2018)

Source: Author's presentation based on data from Table 1 and Table 2 
Figure 1 clearly indicates the correlation between technological readiness competitiveness and global competitiveness of Serbia in selected years. For example, a rank increase of technological readiness competitiveness for 11 places in 2014-2015 is followed by a rank increase of GCI for 7 places in the same year. After that, a little decrease of technological readiness competitiveness for 2 places in 2015-2016 had passed without changing GCI rank. However, next year's ranking of Serbia in both competitiveness categories indicates a completely different correlation between them. A rank decrease of technological readiness competitiveness for 19 places in 2016-2017 but also for 2 places in 2017-2018 is followed by a rank increase of GCI for 4 places in 2016-2017 and 12 places in 2017-2018.

It is a very important finding that the comparison of the first and the last year in the observed period (from 2013-2014 to 2017-2018) shows that Serbia achieved a rank decrease in Technological readiness pillar for 12 places and increase in GCI for 23 places, whereby the score was increased for 0.3 in both competitiveness categories. Although the number of countries covered by WEF Reports (from 2013-2014 to 2017-2018) varied from 137 to 148, previous finding implies that the technological readiness represents a very dynamic competitiveness factor that requires rapid development. In other words, although Serbia has improved the results in the area of technological readiness (for 0.3), its competitiveness in this area has dropped (for 12 places). This points to the fact that other countries have made much more progress in the observed period.

It is also important to note that the level of technological readiness competitiveness of Serbia is higher than the level of its global competitiveness. Nevertheless, there is a trend of constant convergence of these competitiveness categories in recent years. The result of this convergence is that Serbia is positioned in $72^{\text {nd }}$ place in the world with a score of 4.2 according to the Technological readiness pillar in 2017-2018, which is only for 6 places better position than in GCI ( $78^{\text {th }}$ place and a score of 4.1$)$. It is a big difference compared to 2013-2014, when Serbia reached $60^{\text {th }}$ place (score 3.9) in technological readiness competitiveness and $101^{\text {st }}$ place (score 3.8 ) in global competitiveness.

In order to identify the reasons that led to such global position of Serbia in terms of technological readiness, it is necessary to analyse all indicators of this pillar. Table 3 represents score and rank of Serbia in Technological readiness pillar by its indicators in the period from 2013-2014 to 2017-2018.

Data presented in Table 3 show that the most significant increase of technological readiness competitiveness in the period from 2013-2014 to 2017-2018 is recorded in the Availability of latest technologies indicator (rank growth for 31 places and score growth for 0.3). Also, a positive trend is achieved in the following indicators: Firm-level technology absorption (rank growth for 20 places), Fixed-broadband Internet subscriptions/100 pop. (rank growth for 15 places), FDI and technology transfer (rank growth for 14 places), and Internet users \% pop. (rank growth for 11 places). However, these remarkable results could not compensate negative trend in other indicators.

The great decrease of technological readiness competitiveness in the observed period is recorded in the Internet bandwidth $\mathrm{kb} / \mathrm{s} / \mathrm{user}$ indicator (rank decline for even 59 places and score decline for 44.2). Beside Internet bandwidth, the negative trend is also recorded in the Mobile-broadband subscriptions/100 pop. (rank decline for 14 places), although the score is increased for 27.2 . 
Table 3 The score and rank of Serbia in Technological readiness pillar by its indicators (from 2013-2014 to 2017-2018)

\begin{tabular}{|c|c|c|c|c|c|c|c|c|c|c|c|c|}
\hline \multirow{2}{*}{$\begin{array}{l}\text { Indicators of } \\
\text { Technological readiness } \\
\text { pillar }\end{array}$} & \multicolumn{2}{|c|}{ 2013-2014 } & \multicolumn{2}{|c|}{ 2014-2015 } & \multicolumn{2}{|c|}{$2015-2016$} & \multicolumn{2}{|c|}{ 2016-2017 } & \multicolumn{2}{|c|}{$2017-2018$} & \multicolumn{2}{|c|}{$\begin{array}{c}\text { Change } \\
(2013-2014-2017-2018)\end{array}$} \\
\hline & Score & Rank & Score & Rank & Score & Rank & Score & Rank & Score & Rank & Score & Rank \\
\hline $\begin{array}{l}\mathrm{I}_{1} \text { Availability of latest } \\
\text { technologies }\end{array}$ & 4.1 & 118 & 4.2 & 106 & 4.0 & 107 & 4.1 & 103 & 4.4 & 87 & +0.3 & +31 \\
\hline $\begin{array}{l}\mathrm{I}_{2} \text { Firm-level technology } \\
\text { absorption }\end{array}$ & 3.7 & 137 & 3.8 & 127 & 3.8 & 127 & 3.8 & 122 & 3.9 & 117 & +0.2 & +20 \\
\hline $\begin{array}{l}\mathrm{I}_{3} \mathrm{FDI} \text { and technology } \\
\text { transfer }\end{array}$ & 3.9 & 115 & 4.0 & 108 & 3.8 & 110 & 3.7 & 109 & 3.9 & 101 & - & +14 \\
\hline $\mathrm{I}_{4}$ Internet users $\%$ pop. & 48.1 & 67 & 51.5 & 65 & 53.5 & 65 & 65.3 & 56 & 67.1 & 56 & +19 & +11 \\
\hline $\begin{array}{l}\text { I5 Fixed-broadband } \\
\text { Internet subscriptions } \\
\text { /100 pop. }\end{array}$ & 10.2 & 61 & 13.9 & 49 & 15.6 & 50 & 16.8 & 52 & 18.9 & 46 & +8.7 & +15 \\
\hline $\begin{array}{l}\mathrm{I}_{6} \text { Internet bandwidth } \\
\mathrm{kb} / \mathrm{s} / \mathrm{user}\end{array}$ & 70.5 & 29 & 108.9 & 26 & 112.4 & 26 & 20.5 & 90 & 26.3 & 88 & -44.2 & -59 \\
\hline $\begin{array}{l}\text { I } 7 \text { Mobile-broadband } \\
\text { subscriptions / } 100 \text { pop. }\end{array}$ & 40.2 & 41 & 54.8 & 35 & 61.1 & 41 & 71.8 & 39 & 67.4 & 55 & +27.2 & -14 \\
\hline
\end{tabular}

\subsection{Analysis of score and rank of Technological readiness pillar of the top 10 European countries as a group for benchmarking}

In order to analyse the technological readiness competitiveness of Balkan countries, it is relevant to find the competitive position of the top 10 European countries with the best results in technological readiness. The top 10 European countries are the benchmarking group of countries which serves for comparison with 10 Balkan countries. Table 4 shows the scores of top 10 European countries according to indicators within the Technological readiness pillar (2017-2018).

Table 4 The score of top 10 European countries in the indicators of Technological readiness pillar (2017-2018)

\begin{tabular}{|c|c|c|c|c|c|c|c|c|c|c|c|}
\hline 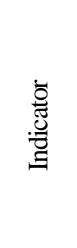 & 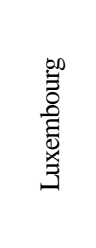 & 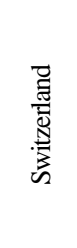 & 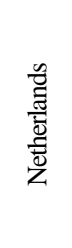 & 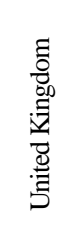 & $\begin{array}{c}\frac{\pi}{0} \\
\frac{D}{3} \\
\tilde{s}\end{array}$ &  & 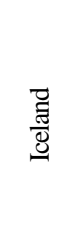 & $\begin{array}{l}\text { ते } \\
\text { Zे } \\
\text { Z }\end{array}$ & $\begin{array}{l}\text { 兰 } \\
\text { 范 } \\
\text { D. }\end{array}$ & 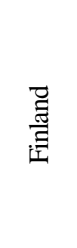 & 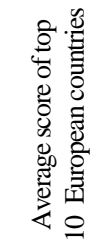 \\
\hline $\mathrm{I}_{1}$ & 6.3 & 6.5 & 6.4 & 6.3 & 6.5 & 6.1 & 6.3 & 6.6 & 6.0 & 6.6 & 6.36 \\
\hline $\mathrm{I}_{2}$ & 5.7 & 5.9 & 5.9 & 5.6 & 6.0 & 5.7 & 5.9 & 5.8 & 5.7 & 5.9 & 5.81 \\
\hline $\mathrm{I}_{3}$ & 5.8 & 5.4 & 5.5 & 5.5 & 5.3 & 5.4 & 4.3 & 5.1 & 4.9 & 4.8 & 5.2 \\
\hline $\mathrm{I}_{4}$ & 97.5 & 89.4 & 90.4 & 94.8 & 91.5 & 89.6 & 98.2 & 97.3 & 97.0 & 87.7 & 93.34 \\
\hline $\mathrm{I}_{5}$ & 36.7 & 46.3 & 42.2 & 39.2 & 36.3 & 38.1 & 37.6 & 40.4 & 42.8 & 31.2 & 39.08 \\
\hline $\mathrm{I}_{6}$ & $8,397.9$ & 269.2 & 196.1 & 449.1 & 505.6 & 107.5 & 997.8 & 269.0 & 239.9 & 216.4 & $1,164.85$ \\
\hline $\mathrm{I}_{7}$ & 90.2 & 103.7 & 87.8 & 91.4 & 125.2 & 80.2 & 104.0 & 101.8 & 124.2 & 153.0 & 106.50 \\
\hline \multirow{2}{*}{$T R P^{*}$} & 6.5 & 6.4 & 6.3 & 6.3 & 6.3 & 6.2 & 6.2 & 6.1 & 6.1 & 6.0 & 6.24 \\
\hline & 1 & 2 & 3 & 4 & 5 & 8 & 10 & 11 & 12 & 16 & - \\
\hline
\end{tabular}

* Note: Technological readiness pillar (upper row - score; lower row - global rank) Source: World Economic Forum, The Global Competitiveness Report, 2017-2018 
With seven countries in the world's top 10, Europe continues to dominate the rankings of technological readiness (Table 4). Furthermore, all of the world's top 5 countries are European countries. Luxembourg records the highest score of Technological readiness pillar among 137 countries (6.5), followed by second-ranked Switzerland (6.4), third-ranked Netherlands (6.3), fourth-ranked United Kingdom (6.3), and fifth-ranked Sweden (6.3). The first five European countries are followed by Germany, Iceland, Norway, Denmark, and Finland.

The scores of top 10 European countries presented in Table 4 show that Norway and Finland record the best score in $\mathrm{I}_{1}$ (Availability of latest technologies), Sweden is the best in $\mathrm{I}_{2}$ (Firm-level technology absorption), Luxembourg in $\mathrm{I}_{3}$ (FDI and technology transfer) and in $\mathrm{I}_{6}$ (Internet bandwidth kb/s/user), Iceland in $\mathrm{I}_{4}$ (Internet users \% pop.), Switzerland in $\mathrm{I}_{5}$ (Fixed-broadband Internet subscriptions/100 pop.), and finally Finland is the best in $\mathrm{I}_{7}$ (Mobile-broadband subscriptions/100 pop).

\subsection{Comparative analysis of indicators in Technological readiness pillar in the Balkan countries}

With the aim of analysing the achievements of Serbia and other Balkan countries in the terms of technological readiness, the scores of all seven indicators within the Technological readiness pillar (2017-2018) of Balkan countries are presented in Table 5. The information

Table 5 The scores of indicators within the Technological readiness pillar of Balkan countries (2017-2018)

\begin{tabular}{|c|c|c|c|c|c|c|c|c|c|c|c|c|c|c|}
\hline 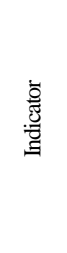 & 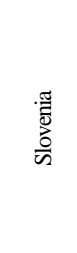 & 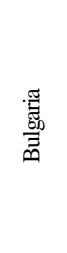 & 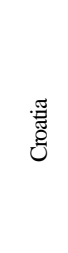 & 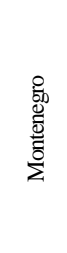 & 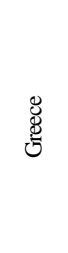 & 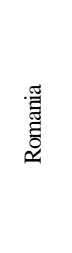 & 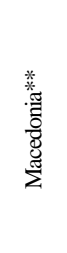 & 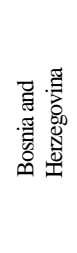 & 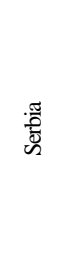 & $\begin{array}{l}\text { 荛 } \\
\text { き }\end{array}$ & 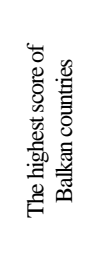 & 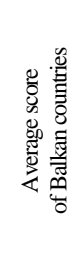 & 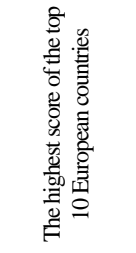 & 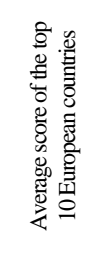 \\
\hline 1 & 2 & 3 & 4 & 5 & 6 & 7 & 8 & 9 & 10 & 11 & 12 & 13 & 14 & 15 \\
\hline $\mathrm{I}_{1}$ & 5.7 & 4.7 & 4.8 & 4.5 & 4.9 & 4.7 & 4.9 & 4.5 & 4.4 & 4.4 & $\begin{array}{c}5.7 \\
\text { Slovenia }\end{array}$ & 4.75 & $\begin{array}{c}6.6 \\
\text { Nor/Fin }\end{array}$ & 6.36 \\
\hline $\mathrm{I}_{2}$ & 4.9 & 4.5 & 4.2 & 4.3 & 4.3 & 4.2 & 4.5 & 4.2 & 3.9 & 4.4 & $\begin{array}{c}4.9 \\
\text { Slovenia }\end{array}$ & 4.34 & $\begin{array}{c}6.0 \\
\text { Sweden }\end{array}$ & 5.81 \\
\hline $\mathrm{I}_{3}$ & 4.2 & 4.7 & 3.7 & 4.4 & 3.7 & 4.1 & 4.1 & 3.8 & 3.9 & 4.9 & $\begin{array}{c}4.9 \\
\text { Albania }\end{array}$ & 4.15 & $\begin{array}{c}5.8 \\
\text { Luxembourg }\end{array}$ & 5.20 \\
\hline $\mathrm{I}_{4}$ & 75.5 & 59.8 & 72.7 & 69.9 & 69.1 & 59.5 & 70.4 & 69.3 & 67.1 & 66.4 & $\begin{array}{c}75.5 \\
\text { Slovenia }\end{array}$ & 67.97 & $\begin{array}{c}98.2 \\
\text { Iceland }\end{array}$ & 93.34 \\
\hline $\mathrm{I}_{5}$ & 28.3 & 23.3 & 24.6 & 18.5 & 32.5 & 20.7 & 17.2 & 17.4 & 18.9 & 8.2 & $\begin{array}{c}32.5 \\
\text { Greece }\end{array}$ & 20.96 & $\begin{array}{c}46.3 \\
\text { Switzerland }\end{array}$ & 39.08 \\
\hline $\mathrm{I}_{6}$ & 239.2 & 175.9 & 119.0 & 202.9 & 68.7 & 155.5 & 53.9 & 98.5 & 26.3 & 57.0 & $\begin{array}{c}239.2 \\
\text { Slovenia }\end{array}$ & 119.69 & $\begin{array}{c}8,397.9 \\
\text { Luxembourg }\end{array}$ & $1,164.85$ \\
\hline $\mathrm{I}_{7}$ & 62.3 & 88.4 & 79.7 & 60.7 & 51.3 & 73.7 & 56.2 & 37.4 & 67.4 & 52.6 & $\begin{array}{c}88.4 \\
\text { Bulgaria } \\
\end{array}$ & 62.97 & $\begin{array}{l}153.0 \\
\text { Finland }\end{array}$ & 106.50 \\
\hline \multirow{2}{*}{$T R P^{*}$} & 5.4 & 5.1 & 5.0 & 4.9 & 4.8 & 4.8 & 4.3 & 4.3 & 4.2 & 4.1 & - & - & - & - \\
\hline & 35 & 39 & 43 & 48 & 50 & 51 & 61 & 69 & 72 & 78 & - & - & - & - \\
\hline \multicolumn{15}{|c|}{$\begin{array}{c}\text { * Note: } \\
\text { ** Note: I } \\
\text { urce: Worl } \\
\text { Legend: }\end{array}$} \\
\hline
\end{tabular}


serves to understand the relative position of Serbia in the group of Balkan countries and European countries, according to each indicator compared to the highest score and the average score of the Balkan countries, as well as the highest score and the average score of the top 10 European countries.

Data presented in Table 5 indicate that the average score of every indicator in the Technological readiness pillar of Balkan countries lags much behind the average score of these indicators of top 10 European countries (see column 13 and 15). Serbia is the ninthranked country out of 10 Balkan countries. According to these data, it is obvious that Balkan countries and especially Serbia have many options for improvement of almost all their performances that determine the technological readiness competitiveness.

Based on the previous analysis, it is possible to identify the list of critical indicators of Technological readiness pillar in Balkan countries. Those indicators need to be priority in development policies and improvements as soon as possible in order to reach the average score of the group. The list of critical indicators of Technological readiness pillar in Balkan countries is shown in Table 6.

Table 6 Indicators within the Technological readiness pillar which require priority of development policy by Balkan countries (2017-2018)

\begin{tabular}{lcc}
\hline \multicolumn{1}{c}{ Country } & $\begin{array}{c}\text { The critical indicators which show the deviations from } \\
\text { the average score of the group of Balkan countries }\end{array}$ & $\begin{array}{c}\text { Number of } \\
\text { critical indicators }\end{array}$ \\
\hline Slovenia & $\mathrm{I}_{7}$ & 1 \\
Bulgaria & $\mathrm{I}_{1}, \mathrm{I}_{4}$ & 2 \\
Croatia & $\mathrm{I}_{2}, \mathrm{I}_{3}, \mathrm{I}_{6}$ & 3 \\
Montenegro & $\mathrm{I}_{1}, \mathrm{I}_{2}, \mathrm{I}_{5}, \mathrm{I}_{7}$ & 4 \\
Greece & $\mathrm{I}_{2}, \mathrm{I}_{3}, \mathrm{I}_{6}, \mathrm{I}_{7}$ & 4 \\
Romania & $\mathrm{I}_{1}, \mathrm{I}_{2}, \mathrm{I}_{3}, \mathrm{I}_{4}, \mathrm{I}_{5}$ & 5 \\
Macedonia & $\mathrm{I}_{3}, \mathrm{I}_{5}, \mathrm{I}_{6}, \mathrm{I}_{7}$ & 4 \\
Bosnia and Herzegovina & $\mathrm{I}_{1}, \mathrm{I}_{2}, \mathrm{I}_{3}, \mathrm{I}_{5}, \mathrm{I}_{6}, \mathrm{I}_{7}$ & 6 \\
Serbia & $\mathrm{I}_{1}, \mathrm{I}_{2}, \mathrm{I}_{3}, \mathrm{I}_{4}, \mathrm{I}_{5}, \mathrm{I}_{6}$ & 6 \\
Albania & $\mathrm{I}_{1}, \mathrm{I}_{4}, \mathrm{I}_{5}, \mathrm{I}_{6}, \mathrm{I}_{7}$ & 5 \\
\hline
\end{tabular}

Source: Author's calculation

Analysis of data presented in Table 6 shows that Serbia and Bosnia and Herzegovina, with 6 critical indicators, are the worst positioned Balkan countries according to the total number of deviations below the average score of Technological readiness pillar (observed by indicators). Albania and Romania show deviations in 5 indicators. Macedonia, Greece, and Montenegro have 4 critical indicators. Croatia has poorer performances in 3 indicators. Bulgaria shows deviations in 2 critical indicators, while Slovenia has only one critical indicator. All mentioned countries must necessarily make a lot of effort to make improvements that bring them closer to the average score of the Balkan countries. This particularly refers to Serbia and Bosnia and Herzegovina.

Beside above analysis, it is very important to identify indicators in which most Balkan countries record a deviation. Table 6 indicates that Internet users $\left(\mathrm{I}_{4}\right)$ need urgent actions in four Balkan countries. All other indicators (Availability of latest technologies $-\mathrm{I}_{1}$, Firm-level technology absorption $-\mathrm{I}_{2}$, FDI and technology transfer $-\mathrm{I}_{3}$, Fixed-broadband Internet subscriptions $-\mathrm{I}_{5}$, Internet bandwidth $-\mathrm{I}_{6}$, Mobile-broadband subscriptions $-\mathrm{I}_{7}$ ) require intervention and improvement by the majority of Balkan countries ( 6 out of 10 countries). 


\subsection{Benchmarking of technological readiness competitiveness of Balkan countries in relation to the top 10 European countries}

The goal of this research segment is to analyse critical indicators in the Technological readiness pillar of Balkan countries with special emphasis on Serbia. This analysis implies the comparison of the average score of the indicators in a Technological readiness pillar of the Balkan countries and top 10 European countries.

Balkan countries recorded worse performances than top 10 European countries in all 7 indicators of the Technological readiness pillar according to average score. The difference between the average score of the top 10 European countries and Balkan countries isachieved as follows (columns 13 and 15 in Table 5): Internet bandwidth $(1,045.16 \mathrm{~kb} / \mathrm{s} / \mathrm{user}$ ), Fixedbroadband Internet subscriptions/100 pop. (18.2), Mobile-broadband subscriptions/100 pop. (43.53), Internet users (25.37 \% pop.), Availability of latest technologies (1.61), Firm-level technology absorption (1.47), and FDI and technology transfer (1.05).

The important conclusion of this benchmarking is that all indicators in the Technological readiness pillar of all Balkan countries deviate from the average score of the top 10 European countries. That indicates complete inferiority of technological readiness performances of Balkan countries in comparison with the top 10 European countries.

The purpose of such benchmarking is to identify benchmark standards that are relevant to guiding and defining development policy, goals, and actions (Bendell, Boulter \& Gatford, 1997; Codling, 1998; Bogetoft, 2012). Benchmark standards are target levels that each Balkan country can set in the technological readiness development strategy on the national level. Such benchmarking allows determination of priorities in development policy for each analysed country. The criteria are based on the urgency or time priority. Firstly, Balkan countries should improve indicators that deviate from the average score of the Balkan countries. When they meet that, the aim should be the average score of the top 10 European countries. After reaching that score, they could set a higher goal - the level of performance of the best countries in the group of top 10 European countries. Systematization of indicators within the Technological readiness pillar according to the priority of their necessary improvement by Balkan countries is presented in Table 7.

Table 7 Specification of indicators within the Technological readiness pillar according to priority of their necessary improvement by Balkan countries

\begin{tabular}{lcc}
\hline Country & $\begin{array}{c}\text { The first level priority of } \\
\text { indicators }- \text { the benchmark is the } \\
\text { average of Balkan countries }\end{array}$ & $\begin{array}{c}\text { The second level priority of indicators } \\
\text { - the benchmark is the average of top } \\
10 \text { European countries }\end{array}$ \\
\hline $\begin{array}{l}\text { Slovenia } \\
\text { Bulgaria }\end{array}$ & $\mathrm{I}_{7}$ & $\mathrm{I}_{1}, \mathrm{I}_{2}, \mathrm{I}_{3}, \mathrm{I}_{4}, \mathrm{I}_{5}, \mathrm{I}_{6}$ \\
Croatia & $\mathrm{I}_{1}, \mathrm{I}_{4}$ & $\mathrm{I}_{2}, \mathrm{I}_{3}, \mathrm{I}_{5}, \mathrm{I}_{6}, \mathrm{I}_{7}$ \\
Montenegro & $\mathrm{I}_{2}, \mathrm{I}_{3}, \mathrm{I}_{6}$ & $\mathrm{I}_{1}, \mathrm{I}_{4}, \mathrm{I}_{5}, \mathrm{I}_{7}$ \\
Greece & $\mathrm{I}_{1}, \mathrm{I}_{2}, \mathrm{I}_{5}, \mathrm{I}_{7}$ & $\mathrm{I}_{3}, \mathrm{I}_{4}, \mathrm{I}_{6}$ \\
Romania & $\mathrm{I}_{2}, \mathrm{I}_{3}, \mathrm{I}_{6}, \mathrm{I}_{7}$ & $\mathrm{I}_{1}, \mathrm{I}_{4}, \mathrm{I}_{5}$ \\
Macedonia & $\mathrm{I}_{1}, \mathrm{I}_{2}, \mathrm{I}_{3}, \mathrm{I}_{4}, \mathrm{I}_{5}$ & $\mathrm{I}_{6}, \mathrm{I}_{7}$ \\
Bosnia and Herzegovina & $\mathrm{I}_{3}, \mathrm{I}_{5}, \mathrm{I}_{6}, \mathrm{I}_{7}$ & $\mathrm{I}_{1}, \mathrm{I}_{2}, \mathrm{I}_{4}$ \\
Serbia & $\mathrm{I}_{1}, \mathrm{I}_{2}, \mathrm{I}_{3}, \mathrm{I}_{5}, \mathrm{I}_{6}, \mathrm{I}_{7}$ & $\mathrm{I}_{4}$ \\
Albania & $\mathrm{I}_{1}, \mathrm{I}_{2}, \mathrm{I}_{3}, \mathrm{I}_{4}, \mathrm{I}_{5}, \mathrm{I}_{6}$ & $\mathrm{I}_{7}$ \\
\hline & $\mathrm{I}_{1}, \mathrm{I}_{4}, \mathrm{I}_{5}, \mathrm{I}_{6}, \mathrm{I}_{7}$ & $\mathrm{I}_{2}, \mathrm{I}_{3}$ \\
\hline
\end{tabular}


Grouping of indicators into different priority levels as shown in Table 7 provides guidance in defining priorities into technological readiness development strategy of each Balkan country. The column for third level priority of indicators (for which the benchmark is the best country among top 10 European countries) does not exist in Table 7, because there is no Balkan country that exceeds the average score of top 10 European countries in any indicator of the Technological readiness pillar.

It is found that Serbia as target country of this analysis has six critical indicators in the first level priority, while Slovenia as best-ranked country in the Balkan group has one indicator in the first level priority (Table 7). A number of critical indicators of other Balkan countries in the first level priority varies from two (Bulgaria) to six (Bosnia and Herzegovina). All other indicators of the Technological readiness pillar are in the second level priority, for which the benchmark is the average of top 10 European countries.

\section{CONCLUSION}

A general conclusion that can be recognized in this paper is that the level of technological readiness competitiveness of Serbian economy is higher than the level of its global competitiveness, but also that there is a trend of constant convergence of this competitiveness categories in recent years. Although Serbia has improved the results in the area of technological readiness in last five-year period from 2013-2014 to 2017-2018 (for 0.3), its global competitiveness in this area has dropped for twelve places (it should be noted that the number of countries covered by WEF Reports in the period from 2013-2014 to 2017-2018 varied from 137 to 148). This points to the fact that other countries have made much more progress in the observed period. It implies that the technological readiness represents a very dynamic competitiveness factor that requires the rapid development of Serbian economy in the future.

Research findings of benchmarking method that is applied in the paper point out the competitive factors (indicators) that need to be improved by Serbia and other Balkan countries and indicate the priority of its improving. The important conclusion of the research is that the average score of all indicators in the Technological readiness pillar of Balkan countries is much lower than the average score of the top 10 European countries. Serbia and Bosnia and Herzegovina, with six critical indicators in the first level of priority, are the worst positioned Balkan countries according to the total number of deviations below the average score of indicators in Technological readiness pillar. Slovenia is the best-ranked country in the Balkan group, with only one indicator in the first level priority.

Internet users as an indicator of Technological readiness pillar need urgent actions in four Balkan countries including Serbia, while all other indicators (Availability of latest technologies, Firm-level technology absorption, FDI and technology transfer, Fixed-broadband Internet subscriptions, Internet bandwidth, and Mobile-broadband subscriptions) require intervention and improvement by six out of ten Balkan countries. After achieving improvements in these indicators which are in the first level of priority, Balkan countries should strive to advance the indicators which should reach the average of the top 10 European countries. 


\section{REFERENCES}

Aboelmaged, G.M. (2014). Predicting e-readiness at firm-level: An analysis of technological, organizational and environmental (TOE) effects on e-maintenance readiness in manufacturing firms. International Journal of Information Management, 34, 639-651.

Aral, S., Brynjolfsson, E. \& Wu, D.J. (2006). Which came first, IT or productivity? The virtuous cycle of investment in enterprise systems. International Conference on Information Systems 2006, Milwaukee.

Avcikurt, C., Altay, H. \& Ilban, O.M. (2011). Critical success factors for small hotel businesses in Turkey: An exploratory study. Cornell Hospitality Quarterly, 52, 153-164.

Bendell, T., Boulter, L. \& Gatford, K. (1997).The Benchmarking Workout. London: Prentice Hall.

Bogetoft, P. (2012). Performance Benchmarking: Measurnig and Managing Performance. New York: Springer.

Buhalis, D. \& Zoge, M. (2007). The strategic impact of the internet on the tourism industry. In M. Sigala, M., Mich, L. \& Murphy, J. (Eds.), Information and communication technologies in tourism (pp. 481-492). Wien: Springer-Verlag.

Bui, X.T., Sankaran, S. \& Sebastian, M.I. (2003). A framework for measuring nationale-readiness. International Journal of Electronic Business, 1 (1), 3-22.

Carr, N. (2004). Does IT matter? Information technology and the corrosion of competitive advantage. Cambridge: Harvard Business School.

Codling, S. (1993). Benchmarking. Hampshir: Gower Publising Limited.

Gilabert, E., Jantunen, E., Emmanouilidis, C., Starr, A. \& Arnaiz, A. (2014). Optimizing e-maintenance through intelligent data processing systems. In: Lee, J. Ni, J., Sarangapani, J. \& Mathew, J. (Eds.), Engineering asset management, Proceedings of the sixth world congress on engineering asset management (pp. 1-10). London: Springer-Verlag.

Gursoy, D. \& Swanger, N. (2007). Performance-enhancing internal strategic factors and competencies: Impacts on financial success. International Journal of Hospitality Management, 26, 213-227.

Ham, S., Kim, W.G. \& Jeong, S. (2005). Effect of information technology on performance in upscale hotels. International Journal of Hospitality Management, 24, 281-294.

Hanafizadeh, P., Hanafizadeh, M. \& Khodabakhshi, M. (2009). Taxonomy of e-readiness assessment measures. International Journal of Information Management, 29 (3), 189-195.

Heeks, R., Molla, A., Boateng, R. \& Hinson, R. (2011). Advancing e-commerce beyond readiness in a developing country: Experiences of Ghanaian firms. Journal of Electronic Commerce in Organizations, 9 (1), 1-16.

Lee, S. \& Connolly, D.J. (2010). The impact of IT news on hospitality firm value using cumulative abnormal returns (CARs). International Journal of Hospitality Management, 29, 354-362.

Low, C., Chen, Y. \& Wu, M. (2011). Understanding the determinants of cloud computing adoption. Industrial Management and Data Systems, 111 (7), 1006-1023.

Lukić, J. \& Mirković, V. (2014). Informaciono-komunikacione tehnologije kao podsticajni faktor evolucije elektronske ka "lean" upravi [Information and Communication Technology as a Motivational Factor of Evolution from Electronic toward „Lean“ Government]. Ekonomika, 60 (2), 199-208.

McAfee, A. \& Brynjolfsson, E. (2008). Investing in IT that makes a competitive difference. Harvard Business Review, 46, 98-107.

Mihalič, T., Praničević, D. \& Arnerić, J. (2015). The changing role of ICT competitiveness: The case of the Slovenian hotel sector. Economic Research-Ekonomska Istraživanja, 28 (1), 367-383.

Mosleh, F. \& Shannak, R.O. (2009). The effective utilization of information and communication technology and its impact on competitive advantage. European Journal of Scientific Research, 29, 302-314.

Muafi, R., Gusaptono, R., Effendi, M. \& Charibaldi, N. (2012). The information technology (IT) adoption process and e-readiness to use within Yogyakarta Indonesian small medium enterprises (SME). International Journal of Information and Communication Technology Research, 2 (1), 29-37.

Mutula, S.M. \& van Brakel, P. (2006). An evaluation of e-readiness assessment tools with respect to information access: Towards an integrated information rich tool. International Journal of Information Management, 26, 212-223.

Naseebullah, S., Dominic, P. \& Khan, M. (2011). A framework of organizational e-readiness impact on eprocurement implementation. Communications in Computer and Information Science, 155, 240-245.

Oztemel, E. \& Polat, T.K. (2006). Technology Readiness Model for Enterprises. In: Pham D.T., Eldukhri, E.E. \& Soroka, A.J. (Eds.), Intelligent Production Machines and Systems (pp. 362-367). Elsevier Science Ltd. 
Petković, M. \& Lukić, J. (2014). New Organizational Forms Supported by the Information and Communication Technology: The Case of Serbian ICT Industry. Facta Universitatis, Series: Economics and Organization, 11 (2), 101-115.

Piccoli, G. (2004). Making IT matter: A manager's guide to creating and sustaining competitive advantage with information systems. CHR Reports, 4 (9), 1-21.

Ray, G., Barneyand, J.B. \& Muhanna, W.A. (2004). Capabilities, business processes, and competitive advantage: Choosing the dependent variable in empirical tests of the resource-based view. Strategic Management Journal, 25, 23-37.

Seyed, K. \& Sattary, H. (2009). Comparison of e-readiness assessment models. Scientific Research and Essay, 4 (5), 501-512.

Siguaw, J.A., Enz, C.A. \& Namasivayam, K. (2000). Adaptation of information technology in US hotels: Strategically driven objectives. Journal of Travel Research, 39, 192-201.

Spyros, A., Euripidis, L. \& Vasiliki, D. (2011). The impact of different types of ICT on innovation performance of Greek firms. Proceedings on the Spiros, European, Mediterranean \& Middle Eastern Conference on Information Systems 2011. Athens, Greece.

Willcocks, L.P. \& Lester, S. (1999). Beyond the IT productivity paradox: Assessment issues. Chichester: Wiley.

World Economic Forum (2013-2014, 2014-2015, 2015-2016, 2016-2017, 2017-2018). The Global Competitiveness Report. Geneva: World Economic Forum, Retrieved from: https://www.weforum.org/reports, Accessed on: 10 February 2018.

\section{ULOGA TEHNOLOŠKE SPREMNOSTI U GLOBALNOJ KONKURENTNOSTI PRIVREDE SRBIJE}

Tehnološka spremnost predstavlja važnu determinantu ekonomskog $i$ društvenog razvoja poslednjih decenija. Stoga, tehnološka spremnost značajno utiče na globalnu konkurentnost nacionalnih ekonomija u savremenom poslovnom okruženju. Cilj ovog rada je da utvrdi nivo konkurentnosti privrede Srbije u pogledu tehnološke spremnosti i da identifikuje kritične faktore za njen budući razvoj. Analiza se zasniva na podacima Svetskog ekonomskog foruma, objavljenim u godišnjim Izveštajima o globalnoj konkurentnosti u periodu od 2013. do 2017. godine. Istraživanje je realizovano primenom komparativne analize i metode benčmarkinga. Rezultati su pokazali značajna odstupanja i negativan trend tehnološke spremnosti Srbije ne samo u poređenju sa evropskim zemljama, već i sa balkanskim zemljama. Zaključci ovog istraživanja mogu poslužiti kao smernice donosiocima odluka u oblasti politike razvoja tehnološke spremnosti Srbije i drugih balkanskih zemalja.

Ključne reči: tehnološka spremnost, konkurentnost, Srbija, zemlje Balkana, zemlje Evrope. 